\title{
In or Out? The Existential Dilemma of Homosexuals in Iris Murdoch's A Fairly Honorable Defeat
}

\author{
Wei Guo ${ }^{1 \& 2}$ \\ ${ }^{1}$ Graduate School, Shanghai International Studies University, Shanghai, China \\ ${ }^{2}$ Lecturer of English, College of Foreign Languages and Cultures, Xiamen University, Xiamen, China \\ Correspondence: Wei Guo, College of Foreign Languages and Cultures, Xiamen University, Xiamen, Fujian \\ Province, China. E-mail: letitiaguo@126.com
}

Received: October 10, 2019 Accepted: November 10, 2019 Online Published: November 29, 2019

doi:10.5539/ells.v9n4p78

URL: https://doi.org/10.5539/ells.v9n4p78

\begin{abstract}
A Fairly Honorable Defeat is one of Iris Murdoch's best acclaimed novels. Critics generally regard it as a triumph of the evil over the good, as embodied in characters Julius King and Tallis Browne. It could also be read from a different perspective as a fairly honorable defeat of the heterosexual love by the homosexual love. But Simon and Axel only win a narrow victory. Their non-normative sexuality still entangles them in gender, social and moral dilemmas. A detailed and close reading of the novel shows Murdoch's concern not only about how the existential dilemma of homosexuals has shaped their gender identity and limited their moral vision and choice, but also about the underlying social problems of power and violence. By bringing into conversation Goffman's theory of stigma, Butler's theory of gender performance and Foucault's view of male friendship, the article argues that Simon and Axel have to struggle between secrecy and disclosure of their sexual identity because of the large homophobic social environment. The insecurity and anxiety engendered by their sexual identity makes it difficult for them to associate with others in sincerity. Their moral weakness and failures are largely occasioned by the social environment.
\end{abstract}

Keywords: Iris Murdoch, A Fairly Honorable Defeat, homophobia, closet, stigma, homosexuality

In her thirteenth novel A Fairly Honorable Defeat published in 1970 (Note 1), Iris Murdoch has successfully portrayed a homosexual couple, Simon Foster and Axel Nilsson. They love, they hate; they doubt, they trust; they quarrel, they reconcile; they err and they forgive. Murdoch moulds them into flesh and blood characters and makes us feel they are real human beings encountering real problems in their life. Her brilliant and detailed portrayal of these lifelike homosexual characters has won her massive acclaim. A Fairly Honorable Defeat is Murdoch's daring attempt to give "her first full-scale portraiture of such a [homosexual] relationship" (Baldanza, pp. 163-164), to put her homosexual characters to the center of the stage and grant them individual voices compared to the peripheral descriptions of the homosexuals in the previous novels. Conradi has exalted Murdoch's effort to realistically present the homosexuals: "The depiction of a happy homosexual relationship between Simon and Axel is itself a small triumph" (Conrai, p. 161). Louis L. Martz also asserts: "Miss Murdoch's bold attempt to display in Axel and Simon a pair of male lovers is a success unprecedented in English fiction" (Martz, p. 55). Cheryl Bove claims that "Murdoch sensitively establishes Simon and Axel as a believable, worthy, and normal couple" (Bove, p. 70). By the same token, David J. Gordon concurs that "the homosexual marriage of Simon and Axel was an extraordinary novelistic achievement in 1970" (Gordon, p. 144). Murdoch, through 'grim realism', successfully delineates the social constraints and prejudices enforced upon the homosexuals as the minority group of the society and their marginalized position in the heteronormative and heterosexist world where homosexuality is always hurled to the undesirable pole in the sexual binarism. The stringent social and moral atmosphere makes the small triumph of the homosexual love between Simon and Axel especially commendable.

Homosexuals, as an important social group of sexual minorities, have always faced the dilemma of staying in or coming out of the closet. Both staying in and coming out of the closet are double-edged. Staying in the closet can in some way guarantee the one in the closet from potential danger of violence, insult, prejudice and other forms of hurt. However, it can also obstruct one from forming the homosocial bonds with other homosexuals. Coming out increases the number of "relational possibilities" (Edwards, p. 48), putting one in touch with the group of 
people "whose economic, institutional, emotional, physical needs and knowledges may have so much in common" (Sedgwick, p. 87). Coming out can also, in some cases lead to "new kinds of alienation and isolation" (Edwards, p. 48). The visibility of the homosexual identity reveals one to both the sympathetic and the unsympathetic. One will be looked at with curious and censuring eyes. Butler also comments on the ambivalence of being out:

For being 'out' always depends to some extent on being "in"; it gains its meaning only within that polarity. Hence, being out must produce the closet again and again in order to maintain itself as "out". In this sense, outness can only produce a new opacity; and the closet produces the promise of a disclosure that can, by definition, never come (Butler, p. 309).

The homosexual character Simon Foster in An Fairly Honorable Defeat is somehow forced to come out of the closet because his feminine attributes unwittingly reveal his sexual identity. Simon is obsessed with his personal appearance, likes to look himself in the mirror and wear fragrant lotion. His homosexual lover Axel Nilsson usually call those habits as 'tribal habits'. Under Axel's incessant warning that "Try to remember you are male not female", Simon tries to change but "he felt that the change was only superficial and he was almost being guilty of insincerity" (FHD29) (Note 2). Actually, Simon enacts what the psychologists and the sexologists term as the gender inversion. Eve Kosofsky Sedgwick, in Epistemology of the Closet, however would like to call it the trope of inversion, one of two gender tropes through which same-sex desire could be understood. Simon in this sense is typically a woman trapped in a man's body. "One vital impulse of this trope is the preservation of an essential heterosexuality within desire itself” (Sedgwick, p. 87).

The dominant heterosexual discourse has implanted in people's mind a deeply ingrained misconception, namely, sex, gender and sexuality exist in relation to each other. If one is biological male, one is expected to display masculine traits in a heteronormative world, in which a person's biological sex supposedly decides his/her social gender and his/her social gender purportedly determines his sexual orientation (Yan, p.41). Butler, however, departs from this common assumption and claims that "gender is 'unnatural', so that there is no necessary relationship between one's body and one's gender. In that case, it will be possible to have a designated 'female' body and not to display traits generally considered 'feminine': in other words, one may be a 'masculine' female or a 'feminine' male (Salih, p. 46). Being a 'feminine male', Simon enjoys cooking, entertaining guests at home, decorating the home and having fresh flowers on display so much so that Axel thinks that he has "the taste of a suburban housewife" (p. 65). Simon also gives advice to Morgan about how to dress properly and beautifully. "I don't think you can quite wear that with that, dear" (p. 178). And, he is not in a stew about expressing his 'feminine expertise'. Simon is apparently a homosexual who plays a female role. There is incongruity among his sex, gender and sexuality. He is biologically male yet socially identifies with female. He is biologically homosexual but psychologically heterosexual. His existence itself "casts doubts on the definitions of sex, gender and sexuality" (Li, p. 26).

Besides Simon Foster, Murdoch has portrayed many 'feminine' males and 'masculine' females in her fictional world. Beautiful Joe in Henry and Cato exudes girly beauty, and Emma Sands in An Unofficial Rose, Mitzi Richardo in An Accidental Man and Patricia Raven in Henry and Cato are presented as "butch" lesbians. Some critics contend that Murdoch's delineation of those characters displays a measure of stereotyping. On the contrary, through deliberate depiction of those 'feminine' male and 'masculine' female characters, Murdoch tries to blur the polarized boundaries between 'masculinity' and 'femininity', male and female, heterosexuality and homosexuality and imparts to us the notion that gender and sexuality are fluid and vulnerable to change rather than fixed and static. "Gender classifications-like any form of categorization-should be disregarded since they are limiting of human individuality and personal autonomy" (Grimshaw, 2007, p. 164). Murdoch would have agreed with Butler in that "there is no 'proper' gender, a gender proper to one sex rather than another, which is in some sense that sex's cultural property. Where that notion of 'proper' operates, it is always and only improperly installed as the effect of a compulsory system" (Butler, pp. 312-313). In other words, gender is not the rightful property of sex, and one should not always align 'masculine' with 'male' and 'feminine' with 'female'.

Hampl criticized Murdoch for desexualising her homosexual characters, claiming that "Murdoch's deferment of homosexual desire complicates homosexuality, for by taking the sex out of homosexual, Murdoch's texts leave only the prefix, meaning same, and the texts therefore provide pals, not partners" (Hampl, p. 659). Murdoch's depiction of "homosexual abstinence" (Grimshaw, 2005, p. 73) in an indirectly way reflect the sociocultural constraint and repressive forces imposed on the homosexuals whose social position is still marginalized, whose voice is silenced and whose desire cannot be articulated and acknowledged. In a heteronormative world where heterosexuality is established as the standard and norm, the homosexual and homoerotic desire is policed and under constant surveillance and has to stay in the closet generally viewed as "an ideational repository for lesbian, 
gay, bisexual and queer individuals whose erotic desires or sexual identities remain hidden or undisclosed to others" (Davis, 2015, p. 960). And the expression of this non-normative desire can never be out in the open but has to be in furtive ways and disguised forms. Actually, there is a homoerotic scene beautifully depicted in $A$ Fairly Honorable Defeat, in which Simon secretively manifests his homoerotic desire. Simon falls in love with a kouros in National Museum at Athens and comes to see it every day. Soon he is not satisfied in watching, and he cannot resist touching it when he is alone with the statue.

The Kouros, which was just six feet high, stood on a pedestal with its navel just about level with Simon's eyes. His hands could reach up as far as the shoulders and could just touch the serrated line of stiff curls at the back. He could not caress the face. But coming back day after day, he caressed everything else. His fingers explored the bones of the long straight legs, the hollow of the thigh, the heavenly curve of the narrow buttocks, the flat stomach and the noble pattern of the rib cage, the pretty eye-shaped navel, the nipples of the breasts, the runnel of the back, the shoulder blades. He lightly stroked the feet, probing between the long-separated toes, he reverently touched the penis. He looked up into the serene divine countenance, hugh-eyed, long-nosed, so enigmatically smiling... (pp. 182-183)

This scene plays a pivotal role in the love relationship between Simon and Axel. It outs Simon to Axel who is a bystander of Simon's homoerotic love scene and provides a chance for them to first know their true sexual identity and then a chance to fall in love.

Another aspect of the gender dilemma that entraps the out homosexuals is that they can not accept who they are and embrace their true nature under the concomitant cultural and social forces. "A heterosexual, heterosexist culture establishes the coherence of those categories in order to perpetuate and maintain what the feminist poet and critic Adrienne Rich has called 'compulsory heterosexuality' - the dominant order in which men and women are required or even forced to be heterosexual" (Salih, p. 49). Woman are assumed to be "innately" sexually oriented only toward men (Rich, p. 29) and men are supposed to be only sexually oriented toward women. In such a culture, homosexuals may feel uncomfortable and anxious about their gender identity because homosexuality is conceived as unnatural and uncivilized compared to heterosexuality. The social environment also hinders the homosexuals from establishing a positive view of themselves. Weeks asserted: "Already by the end of the 1960s there was a burgeoning of a more sophisticated homosexual subculture... and both male homosexuals and lesbians had thriving milieux. But the legacy of guilt and necessary timidity was still present, and a legal and social situation which was ambiguous at best provided no positive stimulus to a more enhanced and positive sense of self and identity" [My Italics] (Weeks, p. 364). In A Fairly Honorable Defeat, Simon is shown to be a diffident person, diffident in his self-identity and diffident in Axel's love for him. Being effeminate in appearance, he is always sneered at by those who are biased about homosexuals. Thus, it is understandable that Simon has always had qualms about his sexual identity before he meets Axel.

But he had felt it as a peculiarity, something rather nice and even perhaps a bit funny, something rather like a game, but definitely odd, to be concealed, giggled about and endless discussed and inspected in the private company of fellow oddities.He had never quite seen it as a fundamental and completely ordinary way of being a human being...” (p. 28)

It is Murdoch's view that "falling in love can be a source of insight, sharpening perception as opposed to coloring it" (Laverty, p. 105). For Murdoch, love reconciles us to our necessary fallibility as it introduces the idea of progress. Love involves an individual's acceptance of vulnerability, being determined by that which exceeds determination, coupled with a desire to bring her determinations into closer accordance with it (Laverty, p. 106). Love helps us to see ourselves anew, helps us to make progress, see reality clearly as it is and bravely accept our vulnerability under the forceful contingent world over which we have no control. Axel's love helps Simon to acquire a new vision of himself and helps him disperse his peculiar feelings about his sexual identity. "He [Axel] made Simon understand for the first time that it was perfectly ordinary to be homosexual" (p. 28).

What causes Simon's anxiety about his sexual identity is the large homophobic social environment in the 1960s. Leslie A. Hall sees 1960 "as a watershed in the changes taking place in British sexual mores" (Hall, 152). The very terms 'permissive' society and 'swinging London' had indicated that the decade heralded a greater flexibility in social, moral and sexual attitudes. Due to the efforts of the Wolfenden Committee, the Sexual Offences Act which passed in 1967 had decriminalized the private sexual acts between consenting male adults. The end of the decade also witnessed the unprecedented Gay Liberation movement. Even though people's attitude had undergone significant changes in a wide range of sexual issues, behavior had altered little. "Their practice is more rigid than their beliefs...There had indeed been a remarkable liberalisation, but it scarcely constitutes a revolution" (Weeks, p. 328). People remain exceptionally chaste by later yardstick in the 1960s and 
their attitude towards homosexuality was still rather conserved and "extremely puritanical, especially towards 'queers' and other obvious social 'deviants' (Weeks, p. 329). The medical profession had great power over those so-called sexual offenders and even took brainwashing measures to force them to conform to the existing norms. Homosexuality, in Foucault's sense, was subjected to the medical gaze. It was considered to be either a biological or psychological illness which required medical treatment. Behaviorists especially showed 'correctional zeal' for homosexuality and invented the notorious aversion therapy "designed to induce nausea when the subject was confronted with the objects of his desire" (Weeks, p. 338). Social scientists also made valiant efforts to unravel the mystery of aetiology of homosexuality. Legal reforms only partially in nature, charges of sexual offences and conspiracy still hung over homosexuals like Damocles' Sword.

The relatively liberal atmosphere and tolerant attitudes toward homosexuality avails Murdoch of a chance to boldly portray the homosexual couple coming out of the closet in her novel. But in the meantime, she is well aware of the homophobic social environment in which many still hold hostility and prejudice towards the homosexuals, animalize them as a different species from the human beings, and ruthlessly impose both physical and verbal violence upon them. Murdoch vividly and realistically portrayed those physical and verbal violence upon homosexuals in A Fairly Honorable Defeat. When Simon attempts to prevent a group of burly youth from launching assaults at a Jamaican man in a Chinese restaurant, he is taunted by the man forthwith. "Look who's there, ... a fucking queer. Listen to his squeaky little voice. Want those pretty looks spoilt mister? ... We don't like pooves. Want to have this wrapped round your head, do you?" (220) [My Italics] If Tallis and others had not arrived in time, Simon would have had to suffer from the physical abuse. "Violence is the instrument of power" (Mason, p. 120). Violence has been used by the group of youth to assert their power, superiority and dominant place in a heterosexual society. Such homophobia-related violence, as a means of oppression, deprives homosexuals of their power of discourses, squelches their spirits to seek for individual freedom and autonomy and leaves them no chance to seek for possibilities in their life.

Both the derogatory words used and the disdain inherent in the tone acutely capture the public sentiments towards homosexuals and accentuate the 'deviant' sexual connotations implicated in homosexuality. When Simon is present before the group of youth, they immediately associate Simon's effeminate appearance with the stereotypes for homosexuals and perceive his difference. "He is reduced in their [our] minds from a whole and usual person to a tainted, discounted one (Goffman, p. 11). By imputing a 'virtual social identity' to Simon, the group of youth categorizes him as a homosexual, a person with a stigma. "They believe the person with a stigma is not quite human. On this assumption they exercise varieties of discrimination, through which they effectively, if often unthinkingly, reduce his life chances. They construct a stigma theory, an ideology to explain his inferiority and account for the danger he represents, sometimes rationalizing an animosity based on other differences" (Goffman, p. 14). To be different is what makes us human and makes us who we are. However, homosexuals are frequently threatened by such stigmatisation of certain attributes that label them as aliens and social outsiders and their personhood may be entirely discredited due to their sexual orientation and gender identity.

In the novel, Simon and Axel as homosexuals not only encounter physical and verbal violence in the public sphere, but also encounter verbal violence in the domestic sphere from those who are close to them. During one of his parents' many cocktail parties, Simon's nephew Peter out of the blue mocks at everyone's hypocrisy to reach a consensus to remain silent about Simon's relationship with Axel, and he especially heaps his reproaches onto Axel who conceals his sexuality in public:

You keep your relationship with Simon a dark secret, don't you! Oh you let us know because we're your so-called dear friends and we're discreet. You can rely on us to tell lies on your behalf. But you'd die if everyone knew. You'd be ashamed! (p. 122)

Why don't you tell everyone in Whitehall that you live with another man? Are you afraid of losing your precious job? Afraid of being called a pansy? Why don't you tell the truth to the world (p. 123).

Peter represents one of many homophobic heterosexuals who always want to draw a demarcation line "to make as large a gulf as possible between 'we' [heterosexuals] and 'they' [homosexuals]" to "protect one's [their] heterosexual credentials and privilege" (Smith, p. 100). Peter's words, nevertheless, have a grain of cruel truth and expose the homosexual's social dilemma in the process of coming out by disclosing their sexuality to others. They fear that the disclosure itself would have serious repercussions on their career or profession. Sedgwick notes that "even at an individual level, there are remarkably few of even the most openly gay people who are not deliberately in the closet with someone personally or economically or institutionally important to them" (Sedgwick, pp. 67-68). Rupert is such a person who is personally, economically and institutionally important to 
Axel. They are college friends at Oxford and later become colleagues working as the civil servants at Whitehall. Axel carefully calculates the risk of disclosing his sexual identity to Rupert, which may have a negative impact on his career. So, all these years when he socializes with them as a friend, he keeps himself closeted and puts on a social masquerade. When Simon first meets Axel at Rupert's home, he has not the faintest idea that he is a homosexual. It is only after Axel has involved himself romantically with Simon that he comes out of the closet to both Rupert and his family. This is a choice of no choice made by Axel. He employs a strategy of collusion which is commonly used by homosexuals to maintain a partial disclosure of his sexual identity. "In this strategy, the structural features of disclosure are played down but the discloser enters into an agreement with a person or persons to keep the information away from certain others" (Davis, 1992, p. 80). By adopting this strategy, Axel has successfully secluded his private life from the public life and alleviated himself of the social pressure weighed on him as a homosexual, but he is also guilty of hiding the truth and fails to be sincere about his sexual preference in public and in the larger community.

The large homosexual unfriendly social environment entangles homosexuals in a moral dilemma in which they struggle between secrecy and disclosure of their sexual identity. Unlike the heterosexuals whose sexual identity is only a tiny and nearly negligent aspect of their life, sexual identity for homosexuals "predominates over other aspects of [their] identity and proves the prime mover of the ways in which they create their life" (Davis,1992, p. 77). Inhabiting "a social matrix, a social structure which assumes, expects and enforces heterosexuality" (Davis, 1992, p. 76), Simon and Axel have to conceal their sexual identity most of the time to safeguard themselves from the potential prejudice, violence and hurt. They have to either tell white lies or camouflage themselves with the imitation of a straight man.

To disguise the true nature of his relationship with Axel, Simon has to lie and refers to Axel euphemistically as "My friend Nisson, with whom I share a house" (p. 143). By calling Axel a friend instead of a lover, Simon intends to curtail the undertone of the sexual nature of their relationship but in an unsuccessfully way. In Sex, Power and the Politics of Identity, Foucault has found that friendship between men has ceased to be a socially accepted way of life in the eighteenth century. Foucault claimed with confidence that "the disappearance of friendship as a social relation and the declaration of homosexuality as a social/political/medical problem are the same process" (Foucault, p. 171). With the emergence of homosexuality and people's acquiring knowledge of it, male friendship is frequently associated with homosexuality. People and society begin to look at the male friendship with suspicious eyes because of the sexual connotations inherent in it. Friendship for men becomes a dangerous way of life. Thus, Simon's calling his relationship with Axel as friendship paradoxically arouses the social suspicion about the nature of their relationship.

While Simon is portrayed to be an effeminate man whose outer appearance betrays his sexual orientation, Axel, Simon's lover and counterpart, is portrayed to be an extremely masculine man who appears to be fairly reserved and austere. One can never perceive Axel's sexual orientation from his appearance, which is his best disguise. For Butler, "gender is performative in the sense it constitutes as an effect the very subject it appears to express. It is compulsory performance in the sense that acting out of line with heterosexual norms brings with it ostracism, punishment, and violence" (Butler, p. 315). To meet with the social expectation and evade alienation and discrimination, Axel, against his own wishes and heart, puts on the compulsory performance of a heterosexual man. Axel hates to lie against his truthful nature. He "detested the necessity for discretion... he blamed the rottenness of a society which still looked askance at such a harmless and natural phenomenon. Sometimes he blamed himself for lacking the courage to be frank about his preferences" (p. 143). Axel's compulsory performance also shows to us the disciplinary power of the society upon a person's gender choice and performance. "Gender is not innate, and it is produced by the disciplinary forces, which compels us to put on performance and act in accordance with what the society thinks fit for a certain gender" (He, p. 137).

Byatt has regarded A Fairly Honorable Defeat as her favorite of Murdoch's later works and lauded the homosexual marriage of Simon and Axel for "they love each other, talk to each other, consider each other, and reach a breaking-point when they automatically discuss Julius's lies and manipulations for what they are" (Byatt, p. 31). Murdoch does inject a lot of strength into these two homosexual characters. Simon, despite being a physically weak person, bravely fights back Julius's bullying and avenges him by dragging him into the swimming pool. Simon fights against his own frivolous nature to establish a stable relationship with Axel and tells the truth in the end even though he seems to tell small lies habitually. Axel, despite being a jealous person, chooses to believe every word of Simon against his best judgement when Simon braves himself to break the truth to him.

But they are also vulnerable human beings who are susceptible to moral errors. What is wrong with their love is, as Rupert intuits, "they are so wrapped up in each other they can hardly see the outside world at all" (p. 10). 
Malak also agrees with Rupert in that "both Axel and Simon are shown as so insecurely absorbed within the shell of themselves that they do not dare to interfere when their action could have averted disaster [Rupert's death]" (Malak, p. 123). Simon misses two chances to save his brother Rupert. The first one is when Julius invites him to peep at the love scene between Rupert and Morgan in the theatre. The second one is when he reveals everything about Julius's prank to fool Rupert and Morgan to fall into love to Axel. They could have told the truth that love between Rupert and Morgan is nothing but a trick manipulated by Julius to either Hilda or Rupert to help dispel the misunderstanding. But instead they make a celebration of their newly reconciled love and "they have been too concerned with their own relationship to see clearly their responsibilities to others" (Reed, Introduction XV). Regrettably they fail to direct their attention and loving gaze to either Rupert who is tormented by remorse and guilt and accidentally gets drowned in the swimming pool or Hilda who is tortured by feelings of betrayal and is deferred by contingencies to save Rupert. For Murdoch, attention is the prerequisite for moral goodness. Attention not only requires "the dissolution of the self" (Freeman, p. 164) by jumping out of the dark cave of self-centredness and the energy "directed outward, toward the other-than-self" (Freeman, p. 164), but also means unceasing care and responsibilities for the others. Simon and Axel are enclosed in the cocoon of their egocentric love, which "dulls one's [their] interests in the surrounding world" (Olsson, p. 167) and their self-enclosed love can "imprison the mind, impeding new understanding... possibilities of fruitful and virtuous action" (Murdoch, 1993, p. 322). In failing to recognize that the highly moral Rupert is equally vulnerable and could blunder out of vanity like ordinary human beings, they have failed in attending to Rupert realistically and beholding him for who he is and perceiving the possibility of change. They could have prevented the tragedy from happening and saved Rupert if they chose to interfere to tell the truth behind the lie rather than let things drift. Murdoch thus shows to us how extremely difficult it is to direct our love and attention to others and how easily and often we neglect our responsibilities for the others especially when we ourselves have to cope with our own predicament in life.

In A Fairly Honorable Defeat, Murdoch for the first time puts two homosexual characters Simon and Axel into the center stage. She not only exults at the strength of the homosexual love between Simon and Axel but also shows their vulnerabilities as ordinary human beings. She also critiques the society as a whole for the injustice imposed upon the homosexuals. In creating a feminine homosexual character Simon, Murdoch has deftly used this homosexual stereotype to challenge the supposed polarization and the unbridgeable boundary between femininity and masculinity. Simon's lover Axel's disguise as a straight man not only reveals the performative nature of both gender and sexuality, but also reflects the gender dilemma confronted by homosexuals in which they have to grapple with secrecy and disclosure of their sexual identity. The heteronormativity, together with the society's hostility and prejudice to the homosexuals, forms an invisible barrier to barricade homosexuals from embracing their true nature. The insecurity thus engendered confine them in the limited space of their love, causing them to be negligent of the reality of the others and their responsibilities for the others. Their sexual identity serves as a crucial factor that constrains their individual freedom, their moral vision and moral choice.

\section{References}

Baldanza, F. (1974). Iris Murdoch. New York: Twayne.

Bove, C. (1993). Understanding Iris Murdoch. Columbia: University of South Carolina.

Butler, J. (1993). Imitation and gender insubordination. In H. Abelove, M. A. Barale \& D. M. Halperin (Eds.), The Lesbian and Gay Studies Reader (pp. 307-320). New York, London: Routlege.

Byatt, A. S. (1976). Iris Murdoch. London: Longman.

Conradi, P. (1986). Iris Murdoch: The Saint and the Artist. London: The Macmillan Press. https://doi.org/10.1007/978-1-349-18236-7

Davis, A. K. (2015). Epiphenomenology of the closet: feeling and fashioning sexuality in everyday life. Sexualities, 18(8), 959-979. https://doi.org/10.1177/1363460715583605

Davis, P. (1992). The role of disclosure in coming out among gay men. In K. Plummer (Ed.), Modern Homosexualities: Fragments of Gay and Lesbian Experience (pp. 75-83). London: Routledge

Edwards, J. (2009). Eve Kosofsky Sedgwick. New York: Routledge. https://doi.org/10.4324/9780203004623

Foucault, M. (1997). Sex, Power and the Politics of Identity. In P. Rabinow (Ed.), Michel Foucault: Ethics, Subjectivity, and Truth, Essential Works of Foucault 1954-1984 (Vol. 1, pp. 163-174). New York: The New Press.

Freeman, M. (2015). Beholding and being beheld: Simone Weil, Iris Murdoch and the ethics of attention. The 
Humanistic Psychologist, 43(2),160-172. https://doi.org/10.1080/08873267.2014.990458

Goffman, I. (1990). Notes on the Management of Spoiled Identity. London: Penguin.

Gordon, D. J.(1995). Iris Murdoch's Fables of Unselfing. Columbia, Mo.: University of Missouri Press.

Grimshaw, T. (2005). Sexuality, Gender and Power in Iris Murdoch's Fiction. Madison: Fairleigh Dickinson University Press.

Grimshaw, T. (2007). Plato, Foucault and beyond: ethics, beauty and bisexuality in The Good Apprentice. In A. Rowe (Ed.), Iris Murdoch: A Reassessment (pp. 163-174). Hampshire: Palgrave Macmillan. https://doi.org/10.1057/9780230625174_14

Hall, L. A. (2005). Sexuality. In P. Addison \& H. Jones (Eds.), A Companion to Contemporary Britain: 1939-2000 (pp. 145-163). Oxford: Blackwell Publishing Ltd. https://doi.org/10.1002/9780470996195.ch10

Hampl, W. S. (2001). Desires deferred: homosexual and queer representations in the novels of Iris Murdoch. Modern Fiction Studies, 47, 657-673. https://doi.org/10.1353/mfs.2001.0060

He, C. Z. (2010). Judith Butler's gender studies and the theory of performativity. Foreign Literature Review, 3, $132-143$

Laverty, M. (2007). Iris Murdoch's Ethics: A Consideration of her Romantic Vision. London \& New York: Continuum.

Li, Y. H. (2002). The many facets of queer theory. Social Sciences Abroad, 2, 23-29.

Malak, A. A.-H. (1983). Demons and angels: The development of the power figure in Iris Murdoch's fiction. Unpublished doctoral dissertation, University of Alberta, Alberta, Canada.

Martz, L. (1986). The London novels. In H. Bloom (Ed.), Iris Murdoch (pp. 39-58). New York \& New Haven \& Philadelphia: Chelsea House Publishers.

Mason, G. (2002). The Spectacle of Violence: Homophobia, Gender and Violence. London \& New York: Routledge. https://doi.org/10.4324/9780203360781

Murdoch, I. (1993). Metaphysics as a Guide to Morals. London: Penguin.

Murdoch, I. (2001). A Fairly Honorable Defeat. New York: Penguin.

Olsson, A. L. (2018). A moment of letting go: Iris Murdoch and the morally transformative process of unselfing. Journal of Philosophy of Education, 52(1), 163-177. https://doi.org/10.1111/1467-9752.12278

Reed, P. J. (2001). A Fairly Honorable Defeat (Introduction). New York: Penguin.

Rich, A. (1993). Compulsory heterosexuality and lesbian existence. In H. Abelove, M. A. Barale \& M. H. David (Eds.), The Lesbian and Gay Studies Reader (pp. 227-254). New York: Routledge.

Salih, S. (2002). Judith Butler. New York, London: Routledge. https://doi.org/10.4324/9780203118641

Sedgwick, E. K. (1990). Epistemology of the Closet. Berkeley, Los Angeles: University of Carolina Press.

Smith, B. (1993). Homophobia: why bring it up? In H. Abelove, M. A. Barale \& M. H. David (Eds.), The Lesbian and Gay Studies Reader (pp. 99-102). New York: Routledge.

Weeks, J. (2014). Sex, Politics, and Society: The Regulation of Sexuality since 1800 (3rd ed.). London \& New York: Routledge. https://doi.org/10.4324/9781315833330

Yan, Z. S. (2004). Judith Butler: desire, body and gender performance. Foreign Theoretical Trends, 4, 38-44.

\section{Notes}

Note 1. Iris Murdoch finished writing A Fairly Honorable Defeat in 1968 though it was published in 1970.

Note 2. Further references to the same edition of the novel A Fairly Honorable Defeat (Murdoch, 2001). A Fairly Honorable Defeat, New York: Penguin) will be indicated by quoting page numbers in parenthesis.

\section{Copyrights}

Copyright for this article is retained by the author, with first publication rights granted to the journal.

This is an open-access article distributed under the terms and conditions of the Creative Commons Attribution license (http://creativecommons.org/licenses/by/4.0/). 